\title{
Solar thermal energy
}

Jianhua Fan, Simon Furbo,' Zhifeng Wang² and Guofeng Yuan²

'Department of Civil Engineering, Technical University of Denmark; ${ }^{2}$ Institute of Electrical Engineering, Chinese Academy of Sciences

\section{Solar energy resources in Denmark and in China}

Denmark, at a latitude of $55-57^{\circ}$, has a temperate climate, with humid, overcast, mild, windy winters and cool summers. Average annual global solar radiation in energy terms on a horizontal surface in Denmark is around $975-1150 \mathrm{kWh} / \mathrm{m}^{2}$ (see Fig. 1). Although the differences are relatively small, six regions with different solar radiation resources were identified for Denmark, and Design Reference Year data have been created for use in calculating the respective performances of solar energy systems for the six regions (Dragsted and Furbo 2012).

In contrast, China, which covers latitudes from 18 to $52^{\circ}$, has a vast territory with six very different climatic zones: tropical, subtropical, warm temperate, medium temperate, cold temperate and plateau. Consequently, China has annual global horizontal solar radiation varying from 930 to $2330 \mathrm{kWh} / \mathrm{m}^{2}$. Global horizontal radiation is the total short-wave radiation that falls from the sky onto a horizontal surface on the ground. It includes both direct solar radiation and the diffuse radiation resulting from reflected or scattered sunlight.

Clearly, the climatic conditions and the availability of the solar energy resource have a significant influence on the design and operation of solar energy systems, including photovoltaic (PV) electricity generation and solar thermal. Huang and Fan have compared solar resources in Denmark and China and pointed out the great potential of solar district heating for China (Huang et al. 2019).

\section{Measuring solar radiation}

Typically, solar radiative power at the site of a solar heating plant is monitored and used as a control signal in operating the plant. For the solar pilot plant located in Tårs, 30 km north of Aalborg (DK), Tian et al. carried out measurements of solar radiation and the operating conditions (Tian et al. 2017). The detailed measurements include global horizontal radiation [W/ $\mathrm{m} 2]$, direct normal irradiation (DNI) [W/ $\left.\mathrm{m}^{2}\right]$ and total radiation $\left[\mathrm{W} / \mathrm{m}^{2}\right]$ on the tilted collector plane of the flat-plate collector field. Direct normal irradiation (DNI), also called beam irradiation, is measured at the surface of the earth at a given location with a surface element perpendicular to the sun. Total radiation, also called

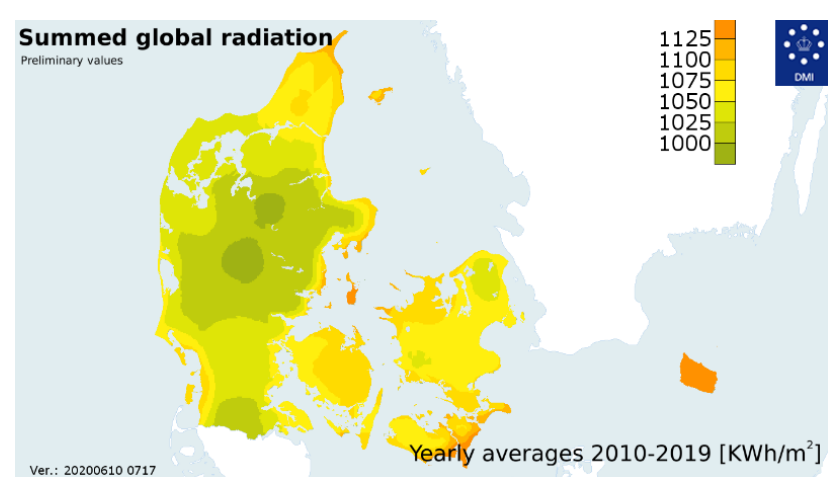

Figure 1 Global horizontal radiation of Denmark expressed as average annual energy density [kWh/m2] (Source: Michael Scharling DMI)

global titled radiation, is measured on a surface with a defined tilt and azimuth. The distribution of diffuse solar irradiance from eight different parts of the sky was monitored closely at a climate station on the campus of the Technical University of Denmark - DTU (Andersen et al. 2015). The influence of clouds on global solar radiation was analysed. These investigations provide valuable input for the development of solar radiation models and the design and operation of solar heating systems.

\section{Modelling solar radiation}

Advanced solar resource modelling and forecasting are necessary for optimal solar energy utilization. The accuracy of seven empirical solar-radiation models, including one developed by DTU, were analysed by Tian et al. (2018). The results show that the DTU model could be used to calculate diffuse radiation, while the anisotropic models were more accurate for calculating the total radiation.

\section{State of the art}

Buildings consumed approximately $42 \%$ of the total final energy consumption of EU member states in 2017. Solar energy could be an interesting and important renewable energy source for space-heating and domestic hot-water services in buildings. Typically, solar

1 https://www.eea.europa.eu/data-and-maps/indicators/final-energy-consumption-by-sector-10/assessment 
thermal utilization for buildings can be categorized into solar domestic hot-water systems, solar combi systems, solar heating plants and solar air-dehumidification systems. These technologies will be touched upon in what follows.

Due to the fluctuating nature of solar radiative power, it is vital to integrate solar heat into advanced heat-storage systems and/or other renewable technologies. In 2010-2013, the Department of Civil Engineering, Technical University of Denmark - DTU Civil, carried out a project with the aim of integrating solar heating systems with so-called (electric) power-to-heat technologies (often abbreviated as $\mathrm{P} 2 \mathrm{H}$ ) based on forecasts of wind power (Furbo et al. 2013).

The application of solar heating systems to single family houses in Denmark is quite limited. However, there is increasing interest in solar district-heating plants because about $65 \%$ of all Danish buildings are connected to district heating. A 'large' central solar heating plant has many advantages compared to small-scale solar heating systems (Tian et al. 2019). Denmark is currently not only the country with the largest amount of total installed capacity and the greatest number of large solar district-heating plants, but also the first and only country with commercial, market-driven solar district-heating plants. At the end of 2019, about 1.6 million m2 (or 160 ha) of solar district-heating plants were in operation in Denmark. Furthermore, about $70 \%$ of the large solar district-heating plants worldwide are currently in operation in Denmark (Weiss and Spörk-Dür 2020). Although according to these statistics Denmark will be overtaken by other countries in the future, the country has still set out clear examples for other countries around the world to follow.

China is the largest country globally in respect of total installed solar energy-system capacity. About 70\% of total solar collector capacity worldwide has been installed in China (Weiss and Spörk-Dür, 2020). The most popular form of solar thermal utilization in China is the solar water heater (SWH). Evacuated tubular collectors (70\%) are currently the most commonly used type of collector, while electric heating elements are the most common auxiliary heat sources for SWH systems, followed by gas water-heaters and air-source heat pumps (Huang et al. 2019).

However, the manufacture of solar collectors in China declined significantly, from 64 million $\mathrm{m}^{2}$ in 2012 to 37 million $\mathrm{m} 2$ in 2017, corresponding to a reduction of around $42 \%$ of the market in 2012 (Huang et al. 2019). More and more solar combi systems are entering the Chinese market. These are solar heating installations providing both space heating and domestic hot water in buildings. Investigations show that large-scale solar district-heating systems are technologically and economically feasible for China (Huang et al. 2019). Solar district heating (SDH) is expected to have a potential for broad application, particularly for areas with low but reasonable population densities, scarce resources, and strict environmental requirements, such as Tibet. Rural villages and small towns with better infrastructure, for example, district-heating networks, will be the best target market for $\mathrm{SDH}$ in the next five years.

\section{Solar collector technologies}

As the 'heart' of a solar heating system, a solar collector converts solar radiation into heat. The main solar collector technologies on the market are flat-plate solar collectors (Fig. 2), evacuated tubular collectors and concentrating solar collectors. Flat-plate solar collectors are the most popular version on the European market (approximately $90 \%$ of the market), while evacuated tubular collectors dominate the Chinese market (approximately $70 \%$ of the market). DTU has carried out ample

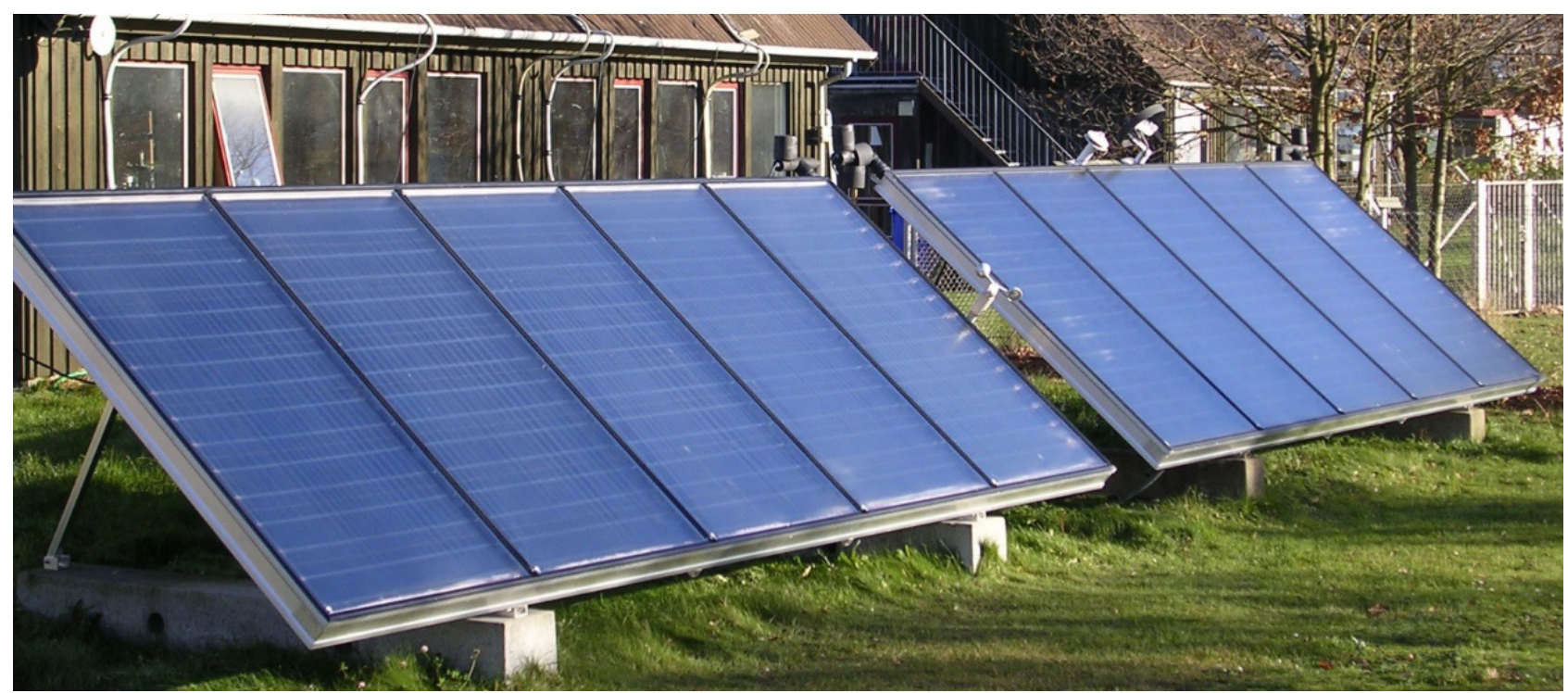

Figure 2 Flat-plate solar collectors used in Danish solar heating plants 
investigation into developing flat-plate solar collectors by means of measurements and computational fluid dynamic simulations (Fan and Furbo 2008). These showed that from 2002 to 2007 the thermal performance of the solar collectors in Danish district-heating plants increased by 29\%, 39\%, 55\% and 80\% for a mean solar-collector fluid temperature of $40^{\circ} \mathrm{C}, 60^{\circ} \mathrm{C}, 80^{\circ} \mathrm{C}$ and $100^{\circ} \mathrm{C}$ respectively. The expected lifetime of the solar collectors used in Danish solar heating plants is greater than thirty years.

Differently designed evacuated tubular collectors were also tested side by side at DTU's test facility. The collector efficiency of a tracking compound parabolic collector was measured by Yuan et al. (Yuan et al. 2020).

As concentrating tracking solar collectors are more efficient at high operating temperatures, they should be used preferentially in solar heating plants operating at high temperatures. The long-term thermal performance of a hybrid solar collector field with flat-plate solar collectors and parabolic-trough collectors in series was measured and simulated using Trnsys (Tian et al. 2018). A quasi-dynamic model for the collector field was developed and validated by the measurements (Tian et al. 2018).

\section{Heat storage}

Heat storage is considered a vital component of solar heating systems. Types of heat storages can be divided into three categories: sensible heat storage, latent heat storage, and chemical heat storage.

The main forms of sensible heat storage are: hot water tanks, water pit heat storage, borehole heat storage, and aquifer heat storage.

Research on hot water tanks and water pit heat storage aims to achieve higher storage efficiency and thermal stratification in the storage unit. Fan and Furbo carried out experimental and numerical investigations on the heat loss of a hot-water tank and the influence of heat loss on thermal stratification in the tank (Fan and Furbo 2012a, 2012b). It was found that, due to heat loss from the side of the tank, relatively colder fluid moves to the bottom of the tank along the tank wall, while warmer fluid in the middle of the tank moves to the top of the tank. This natural convection helps create thermal stratification in the tank. The recent developments of types of water pit heat storage in connection with district heating in Denmark have attracted worldwide attention (Tian et al. 2019). Simulation models, developed through collaboration between Denmark and China, were validated against measurements of a $3000 \mathrm{~m}^{3}$ water pit heat storage facility (Bai et al. 2020).

Latent forms of heat storage can make use of organic and inorganic phase change materials (PCM) as heat storage materials. The inorganic PCM has the advantage of having a high energy density, high heat-transfer rate and low cost, and is non-flammable. Salt hydrates, such as sodium acetate trihydrate (SAT), are the most frequently applied inorganic PCMs. SAT has the property of stable supercooling to a high degree, which can be used to store latent heat for a long time with minimal heat loss. Modularized heat-storage units utilizing stable supercooling ${ }^{2}$ of SAT was developed and tested at DTU. Successful supercooling was achieved for certain heat-storage designs. With the support of the SDC PhD programme and the EU COMTES project, a complete heating system with developed heat-storage units was constructed and demonstrated on the DTU campus under real environment conditions (Englmair et al. 2020; see Fig. 3). The tests showed promising results. However, the flat heat-storage units were too expensive. Therefore, a tank-in-tank PCM heat-storage unit was developed with the aim of reducing the cost of storage by using mass-produced, standard hot-water tanks (Englmair et al. 2020).

\section{Solar heating systems}

Depending on user type, small or medium-size solar heating systems are available for single family houses or multiple-storey buildings and solar heating plants

2 Supercooling, also known as undercooling, is the process of lowering the temperature of a liquid or a gas below its freezing point without it becoming a solid

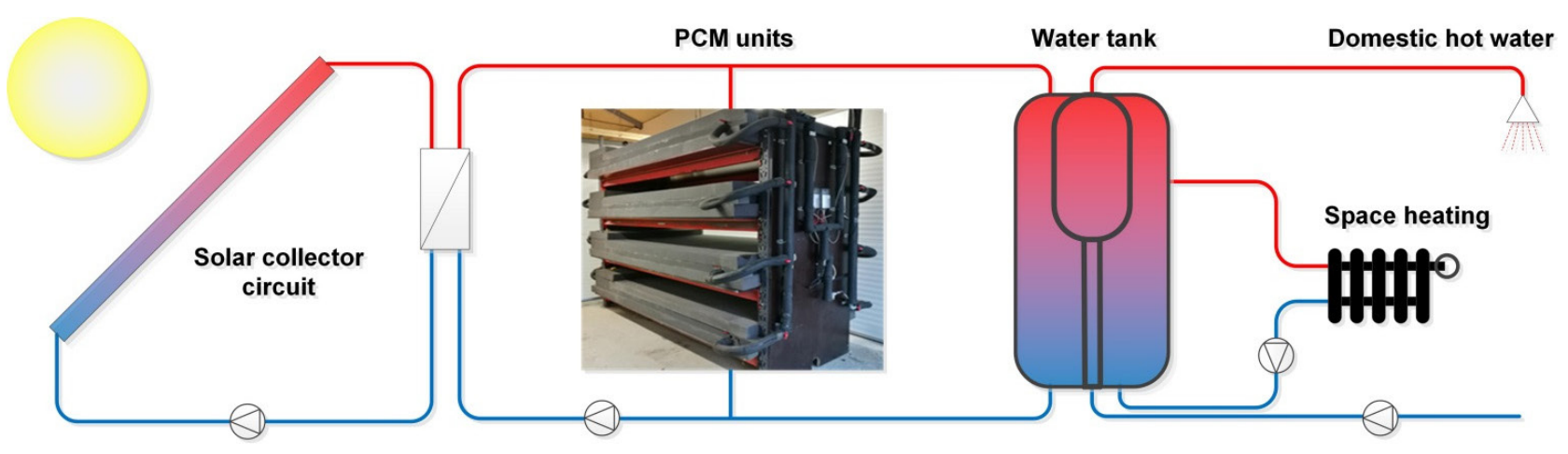

Figure 3 Demonstration of a solar combi system with heat-storage units utilizing stable supercooling of SAT (Englmair et al. 2019) 


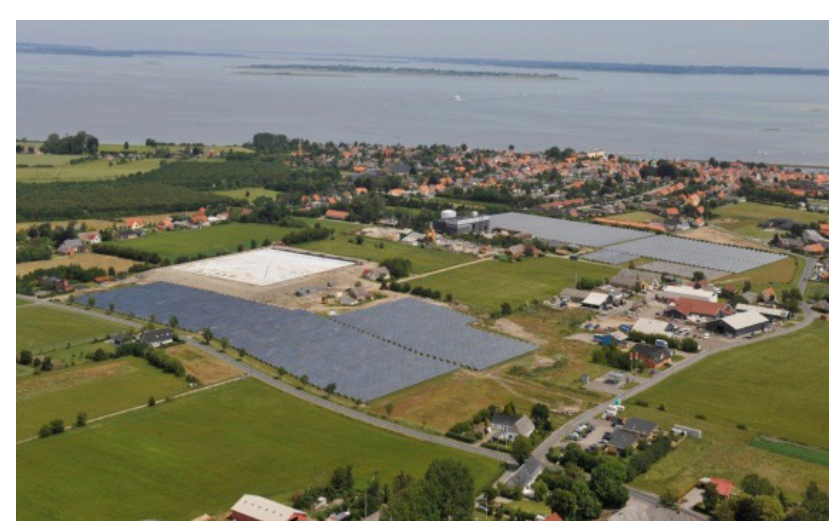

A Marstal plant $\left(33,300 \mathrm{~m}^{2}\right)$

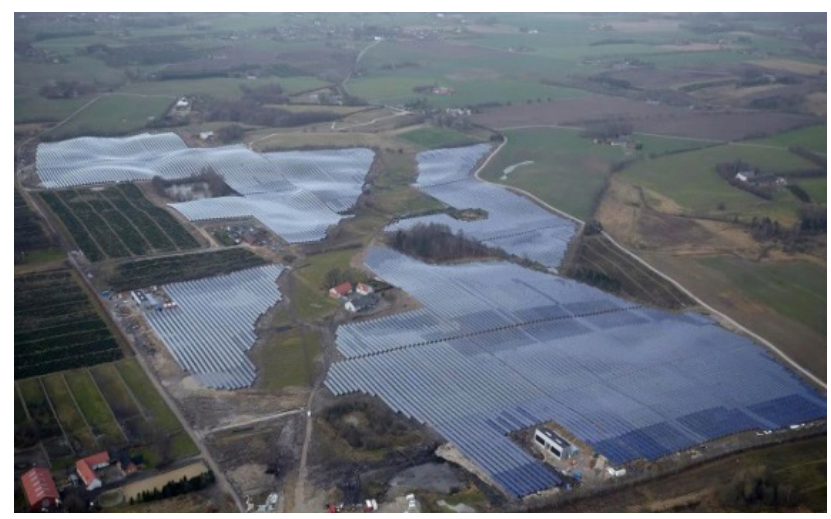

C Silkeborg plant $\left(156,694 \mathrm{~m}^{2}\right)$

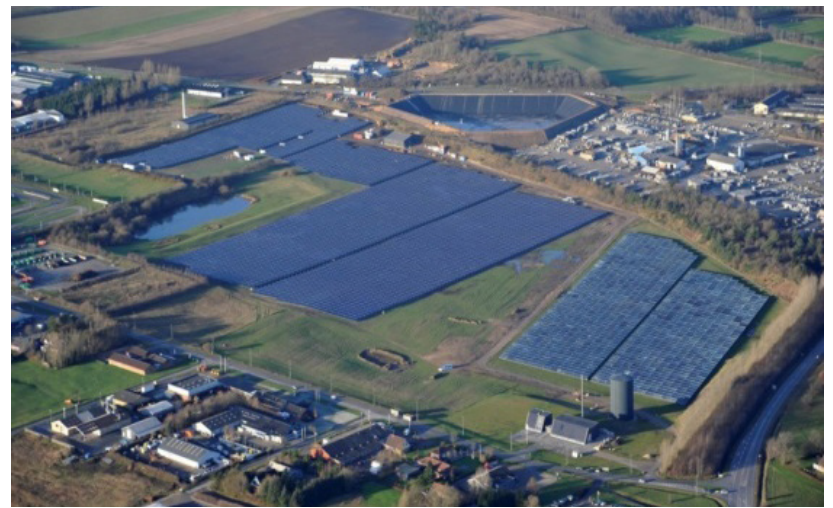

B Vojens plant $\left(70,000 \mathrm{~m}^{2}\right)$

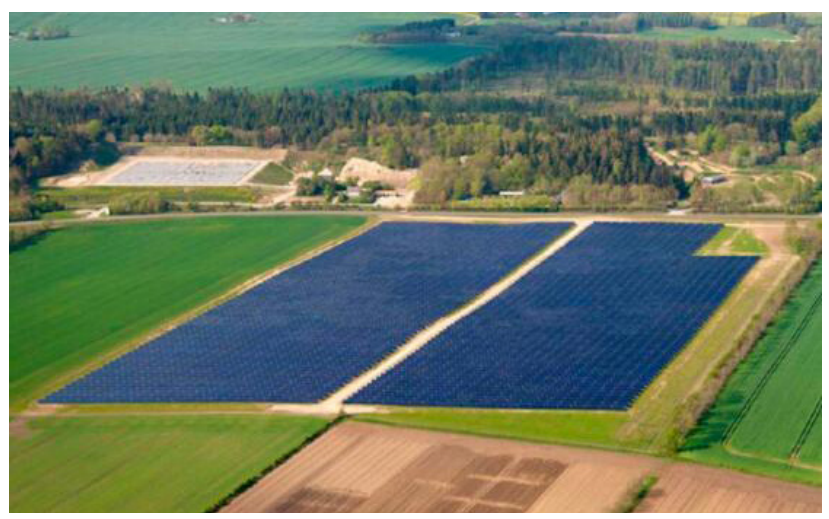

D Dronninglund plant $\left(37,573 \mathrm{~m}^{2}\right)$

Figure 4 Danish solar heating plants (Source: Arcon-Sunmark, http://arcon-sunmark.com/)

for district heating. Differently designed solar combi systems for single family houses were investigated both experimentally and numerically (Andersen et al. 2014). The systems were based on highly stratified tanks with variable auxiliary heated volumes. They were also equipped with an intelligent control system that optimizes the operation of a heat pump/electric element combination based on forecasts of solar energy production, variable electricity prices and heating demand. The energy savings of solar heating systems in practice, compared to a traditional heating system fuelled by natural gas, was determined for single-family Danish houses (Furbo et al. 2011), being typically of the order of 500-800 kWhth per $\mathrm{m}^{2}$ solar collector.

Figure 4 shows four Danish solar heating plants as examples. Numerous experimental campaigns and ample theoretical/numerical analyses and explorations exist of the thermal performance of solar heating plants. For example, a Trnsys model of the Marstal (DK) solar district-heating system was developed and validated by measurements (Fan et al. 2017), whereas Furbo et al. summarized the long-term measurements of 48 solar heating plants in Denmark with flat-plate solar collectors in the period 2012-2016. The measured yearly thermal performances per collector area varied between $313 \mathrm{kWh}$ h/ $/ \mathrm{m}^{2}$ and $577 \mathrm{kWhth} / \mathrm{m}^{2}$. Variable weather conditions and the location and temperature level of the plant are the major causes of the differences (Furbo et al. 2018). Also, Tian et al. investigated the annual thermal performance of a hybrid solar district-heating plant with flat-plate collectors and CSP collectors (Tian et al. 2017), leading to valuable inputs for the design of such hybrid solar heating plants, especially for areas with high solar radiation as a resource

\section{System integration of solar heating systems}

One important topic is the integration of solar heating systems into overall energy systems. For example, single-family solar heating systems could be integrated with the electrical grid by means of smart solar tanks with variable auxiliary volumes (Perers et al. 2010). Through intelligent control of the system, it is possible to use the solar tanks as flexibility options for the electrical grid (Andersen et al. 2014). For example, booster heat pumps or resistor heating elements could be used. Huang and Fan investigated household solar heating systems in combination with different sources of auxiliary energy, for instance, air-source heat pumps, ground-source heat pumps, gas boilers, etc. The optimal solar collector area and the solar fraction were determined for the different combinations (Huang et al. 2019b). With applications of large forms of thermal energy storage in district-heating plants, it becomes feasible to integrate different renewable energy technologies (such as solar heat, wind power, and biomass) into the overall energy system. For centralized dis- 
trict-heating systems, Huang and Fan investigated the integration of air-source heat pumps, ground-source heat pumps, large-scale heat storage and gas boilers with solar heat (Huang et al. 2019a). The optimal solar fraction for an SDH with heat pumps was found to be $11-33 \%$. The integration of solar heating with groundsource heat pumps was investigated for a village in the suburb of Beijing. It is essential to ensure the thermal balance of the ground optimal matching of the size of the ground heat storage, the collector area and the tank volume (Huang et al. 2020).

\section{Economic analysis}

The key success factor for solar heating is a good long-term economic balance (costs/benefits), while reducing greenhouse gas emissions as much as is reasonable or possible. In principle, one should distinguish between the overall cost/benefit picture for an investor in a solar heating system and the overall cost/benefit picture for society. The former should be clear; the latter includes the system integration aspects (e.g., thermal network, electricity grid, gas grid) for a whole region or country, as well as the external (environmental) costs. This last item is currently a subject of research worldwide, and only initial rough results (with ample simplifying hypotheses) are available in the scientific literature. In the following, we concentrate on the costs for the investor and operator of solar heating systems.

The 'levelized cost of heat' ( $\mathrm{LCOH})$ is widely used in economic analysis for a solar heating system; it can be defined as follows (Huang et al. 2019, 2019):

$$
L C o H=\frac{I_{0}-S_{0}+\sum_{t=1}^{T} \frac{C_{t}(1-T R)-D E P_{t} \cdot T R}{(1+r)^{t}}-\frac{R V}{(1+r)^{T}}}{\sum_{t=1}^{T} \frac{E_{t}}{(1+r)^{t}}}
$$

where the LCoH can be expressed in [DKK / $\mathrm{kWh}$ th ; is the initial investment for the whole system, [DKK $]$; stands for subsidies and incentives $[D K K$; refers to the operation and maintenance costs in year $\mathrm{t}[\mathrm{DK} / \mathrm{K}]$; is the tax rate $[\% / 100]$; is the asset depreciation in year $t[D K K K]$; stands for the residual value of the system at the end of life $[D K K$ ]; is the total thermal energy demand in year $\mathrm{t}\left[\mathrm{RWh}_{\mathrm{th}}\right]$; is the discount rate $[\% / 100]$; and is the overall lifetime of the system [year]. The $\mathrm{LCOH}$ is the fictitious average price for heat that the investor should receive (i.e., as revenue when selling the heat, or the avoided price for not having to buy heat) so that the investment and operational costs break even.

The LCoH enables solar heating systems using different technologies to be compared. In recent work, different types of solar heating system were applied to five European countries: Austria, Switzerland, Denmark, Germany and France. It was shown that without subsidies most solar heating systems have a higher LCOH than the reference conventional heating systems without solar, except for some solar domestic hot-water systems
(Louvet et al. 2019). The reference systems without solar assistance are theoretical heating systems meeting the same useful heat demand as the solar-assisted heating systems. To make solar heating systems economically competitive in the market, supporting policies such as tax relief and subsidies are needed. The economics of solar heating systems were also investigated for single family houses in China (Huang et al. 2019b). There is an optimal solar fraction with the lowest system LCoH. Depending on the design of the system, the optimal solar fraction may vary significantly.

Thermo-economic analyses were also carried out for large solar heating plants. Tian et al. calculated the LCoH for a solar district-heating plant in Denmark with both flat-plate and parabolic-trough solar collectors (Tian et al. 2018). By design optimizations, the $\mathrm{LCOH}$ could reach $0.36 \mathrm{DKK} / \mathrm{kWh} \mathrm{h}_{\mathrm{th}{ }^{\prime}}$ compared to a typical price for heat in Denmark of about 0.6 DKK/RWh with tax. Huang and Fan investigated the potential of differently designed solar district-heating systems for China (Huang et al. 2019a). In combination with a PEST (policy, economics, social, and technology) analysis and a SWOT (strengths, weaknesses, opportunities, and threats) analysis, the LCOH was used to identify potential areas of development for solar heating plants in China (Huang et al. 2019). It is believed that SDH has a broad potential for application in China, especially in the west and north-west of the country, where there are abundant solar/land resources and favourable policies.

\section{Conclusions}

Based on the information available in the scientific and technical literature on solar heating applications, the following conclusions can be drawn:

1. Since solar energy-based technologies have a significant influence on system performance, detailed measurements and accurate prediction models of solar irradiance are necessary.

2. Denmark is the world front-runner in the field of solar district heating, while China has the world's largest solar thermal market, with a share of approximately $70 \%$ of the world's total capacity. The research collaboration on solar district heating between China and Denmark will therefore be beneficial for the development of solar heating technologies.

3. Thermal energy storage is an important component of any solar heating system. Research is still necessary in order to develop more efficient forms of heat storage with a high degree of thermal stratification and minimal heat loss.

4. In order to develop solar heating systems that are economically competitive in the heat market, support policies, such as tax relief and subsidies, will still be needed until investment costs come down. 


\section{References}

Andersen, E., Chen, Z., Fan, J., Furbo, S., Perers, B. 2014. Investigations of intelligent solar heating systems for single family house. In: Energy Procedia.

Andersen, E., Nielsen, K.P., Dragsted, J., Furbo, S. 2015. Measurements of the Angular Distribution of Diffuse Irradiance. Energy Procedia 70, 729-736.

Bai, Y., Wang, Z., Fan, J., Yang, M., Li, X., Chen, L., Yuan, G., Yang, J. 2020. Numerical and experimental study of an underground water pit for seasonal heat storage. Renew. Energy 150, 487-508.

Dragsted, J., Furbo, S., 2012. Solar radiation and thermal performance of solar collectors for Denmark, DTU Civil Engineering Reports.

Englmair, G. 2019. Combined short and long-term heat storage with sodium actetate trihydrate for solar combi-systems Gerald Englmair. Technical University of Denmark

Englmair, G., Furbo, S., Dannemand, M., Fan, J. 2020a. Experimental investigation of a tank-in-tank heat storage unit utilizing stable supercooling of sodium acetate trihydrate. Appl. Therm. Eng. 167, 114709.

Englmair, G., Kong, W., Brinkø Berg, J., Furbo, S., Fan, J. 2020b. Demonstration of a solar combi-system utilizing stable supercooling of sodium acetate trihydrate for heat storage. Appl. Therm. Eng. 166.

Englmair, G., Moser, C., Schranzhofer, H., Fan, J., Furbo, S. 2019. A solar combi-system utilizing stable supercooling of sodium acetate trihydrate for heat storage: numerical performance investigation. Appl. Energy 242, 1108-1120.

Fan, J., Furbo, 5. 2008. Buoyancy effects on thermal behavior of a flat-plate solar collector. J. Sol. Energy Eng. Trans. ASME 130, 021010.

Fan, J., Furbo, S. 2012a. Buoyancy driven flow in a hot water tank due to standby heat loss. Sol. Energy 86, 3438-3449.

Fan, J., Furbo, S. 2012b. Thermal stratification in a hot water tank established by heat loss from the tank. Sol. Energy 86, 3460-3469.

Fan, J., Huang, J., Andersen, O.L., Furbo, S. 2017. Thermal performance analysis of a solar heating plant. ISES Sol. World Congr. 2017 - IEA SHC Int. Conf. Sol. Heat. Cool. Build. Ind. 2017, Proc. 291-300

Furbo, S., Dannemand, M., Perers, B., Andersen, E., Fan, J., Bacher, P., Madsen, H., Halvgaard, R., Nielsen, H.A., Pagh Nielsen, K., Lundholm, S.C., Hansen Sass, B., Engberg Ped- ersen, T., Nymann Rud, J., Harley Hansen, K. 2013. Solar/ electric heating systems for the future energy system, DTU Civil Engineering Reports. Technical University of Denmark, Department of Civil Engineering.

Furbo, S., Dragsted, J., Perers, B., Andersen, E., Bava, F., Nielsen, K.P. 2018. Yearly thermal performances of solar heating plants in Denmark - Measured and calculated. Sol. Energy 159, 186-196.

Furbo, S., Fan, J., Andersen, E., Perers, B., Chen, Z. 2011. Energy savings for solar heating systems in one family houses. In: 3Oth ISES Biennial Solar World Congress 2011, SWC 2011.

Huang, J., Fan, J., Furbo, S., 2019a. Feasibility study on solar district heating in China. Renew. Sustain. Energy Rev. 108, 53-64.

Huang, J., Fan, J., Furbo, S. 2020. Demonstration and optimization of a solar district heating system with ground source heat pumps. Sol. Energy 202, 171-189.

Huang, J., Fan, J., Furbo, S., Chen, D., Dai, Y., Kong, W. 2019b. Economic analysis and optimization of household solar heating technologies and systems. Sustain. Energy Technol. Assessments 36, 100532

Huang, J., Fan, J., Furbo, S., Chen, D., Dai, Y., Kong, W. 2019c. Economic analysis and optimization of combined solar district heating technologies and systems. Energy 186, 115886.

Huang, J., Fan, J., Furbo, S., Li, L. 2019d. Solar water heating systems applied to highrise buildings-lessons from experiences in China. Energies 12, 3078.

Huang, J., Tian, Z., Fan, J. 2019e. A comprehensive analysis on development and transition of the solar thermal market in China with more than $70 \%$ market share worldwide. Energy 174, 611-624

Louvet, Y., Fischer, S., Furbo, S., Giovannetti, F., Helbig, S., Köhl, M., Mugnier, D., Philippen, D., Veynandt, F., Vajen, K. 2019. Economic comparison of reference solar thermal systems for households in five European countries. Sol. Energy 193, 85-94.

Perers, B., Furbo, S., Andersen, E., Fan, J. 2010. Solar Electric heating systems using smart solar tanks and variable electricity costs. In: Eurosun 2010.

Tian, Zhiyong, Perers, B., Furbo, S., Fan, J. 2017. Analysis of measured and modeled solar radiation at the tars solar heating plant in Denmark. In: Proceedings of the 11th ISES Eurosun 2016 Conference. International Solar Energy Society, pp. 1536-1542. 
Tian, Z., Perers, B., Furbo, S., Fan, J. 2017. Annual measured and simulated thermal performance analysis of a hybrid solar district heating plant with flat plate collectors and parabolic trough collectors in series. Appl. Energy 205, 417-427.

Tian, Z., Perers, B., Furbo, S., Fan, J. 2018. Analysis and validation of a quasi-dynamic model for a solar collector field with flat plate collectors and parabolic trough collectors in series for district heating. Energy 142, 130-138.

Tian, Zhiyong, Perers, B., Furbo, S., Fan, J. 2018a. Thermo-economic optimization of a hybrid solar district heating plant with flat plate collectors and parabolic trough collectors in series. Energy Convers. Manag. 165, 92-101.

Tian, Zhiyong, Perers, B., Furbo, S., Fan, J., Deng, J., Dragsted, J. 2018b. A comprehensive approach for modelling horizontal diffuse radiation, direct normal irradiance and total tilted solar radiation based on global radiation under Danish climate conditions. Energies 11, 1315.
Tian, Zhiyong, Perers, B., Furbo, S., Fan, J., Zourellis, A. 2018c. Long term measured and simulated performance of a combined solar district heating plant with flat plate collectors and parabolic trough collectors in series Long term measured and simulated performance of a combined solar district heating plant with flat. In: 5th International Solar District Heating Conference. pp. 1-3.

Tian, Z., Zhang, S., Deng, J., Fan, J., Huang, J., Kong, W., Perers, B., Furbo, S. 2019. Large-scale solar district heating plants in Danish smart thermal grid: Developments and recent trends. Energy Convers. Manag. 189, 67-80.

Yuan, G., Fan, J., Kong, W., Furbo, S., Perers, B., Sallaberry, F. 2020. Experimental and computational fluid dynamics investigations of tracking CPC solar collectors. Sol. Energy $199,26-38$.

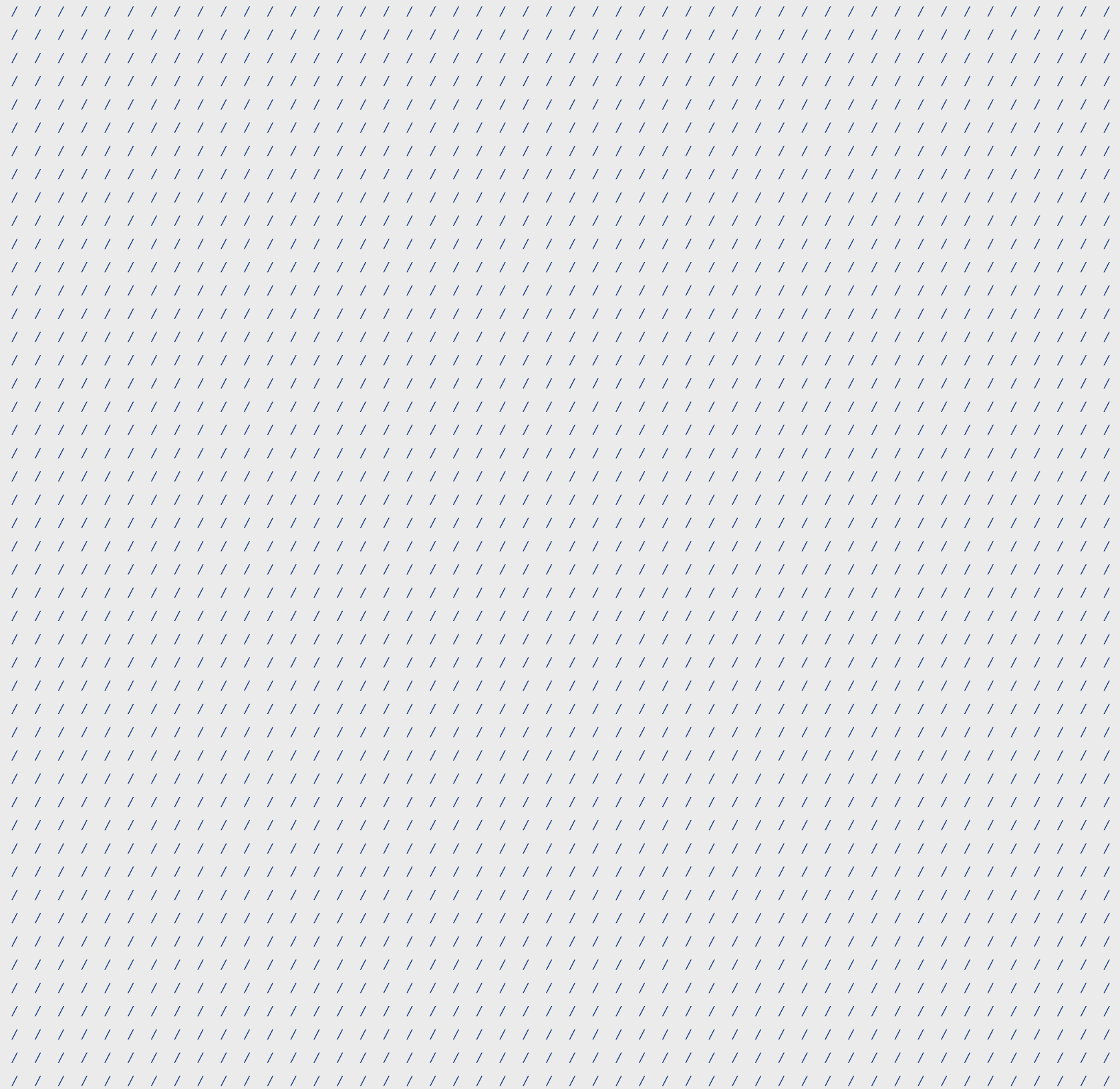

